\title{
PERSONAL ADJUSTMENT FEMALE STUDENT'S BROKEN HOME IN MAN 2 TANAH DATAR
}

\author{
Ira Detriana ${ }^{1}$
}

iradetriana@gmail.com

\begin{abstract}
Abstrak: Pokok permasalahan dalam artikel ini adalah gambaran penyesuaian diri siswi broken home yang berprestasi di MAN 2 Tanah Datar. Tujuan pembahasan ini untuk mengetahui bentuk penyesuaian diri siswi broken home yang berprestasi di MAN 2 Tanah Datar. Jenis penelitian yang penulis gunakan adalah jenis penelitian kualitatif. Teknik pengumpulan data yang penulis gunakan observasi langsung (participant observation) dan wawancara mendalam (depth interview). Analisis data dilakukan secara deskriptif kualitatif. Dari penelitian yang penulis lakukan di lapangan dapat disimpulkan bahwa dari data yang ada diketahui bentuk penyesuaian diri yang dimiliki siswi berbeda ketika di lingkungan keluarga dan di sekolah. Di lingkungan keluarga mereka cenderung menunjukkan bentuk penyesuaian diri negatif. Namun, ketika di sekolah mereka mampu menyesuaikan diri secara positif dan berprestasi. Penyesuaian diri siswi broken home yang berprestasi di MAN 2 Tanah Datar dipengaruhi oleh faktor-faktor berikut: kematangan emosional, kondisi lingkungan keluarga dan sekolah.
\end{abstract}

Kata kunci: penyesuaian diri, siswi broken home

\section{PENDAHULUAN}

Keluarga sebagai unit sosial terkecil, di mana proses belajar pertama kali diperoleh di lingkungan keluarga. Proses belajar tersebut berlaku sepanjang hidup individu, mulai dari bayi, anak-anak, remaja hingga dewasa. Dalam rentang kehidupannya anak mengalami proses tumbuh dan berkembang di keluarga. Melalui proses tersebut banyak hal yang diperoleh anggota keluarga salah satunya pembentukan jati diri. Suasana dan struktur keluarga sangat mempengaruhi penyesuaian diri anak di lingkungan. Anak yang dibesarkan di keluarga harmonis akan memiliki penyesuaian diri positif.

Namun seiring berjalannya waktu akan terjadi perubahan pada strukur dan suasana keluarga tersebut yang akan memberi dampak pada penyesuaian diri anak

\footnotetext{
${ }^{1}$ Penulis merupakan guru di SMK N 1 Batipuh
} 
di lingkungan. Perubahan tersebut akan membentuk penyesuaian diri yang salah pada anak ketika berinteraksi dengan lingkungan. Fenomena di lapangan saat ini semakin maraknya kasus broken home yang sangat berdampak khususnya dalam penyesuaian diri remaja. Remaja yang dikenal sebagai usia bermasalah membutuhkan bimbingan khususnya dari orang tua/keluarga. Namun, kenyataannya sekarang kondisi yang dialami remaja ialah kondisi keluarga yang berantakan atau dikenal dengan broken home.

Hal ini terjadi karena perceraian orang tua, pertengkaran antara Ayah dan Ibu, orang tua terlalu sibuk bekerja, salah satu/kedua orang tua meninggal. Akibatnya banyak remaja yang mengalami kegagalan dalam penyesuaian diri. Kegagalan penyesuaian diri remaja ini tergambar dari perilakunya di sekolah, seperti: Siswi bermasalah dalam menjalin hubungan sosial dengan rekannya karena remaja broken home cenderung memiliki tingkat emosionalitas yang tinggi, mengisolasi diri, kebiasaan Siswi tidak bisa menghindar dari perilaku menyimpang meskipun sudah diberi peringatan dan hukuman, kebiasaan berbohong, membangkang dan hiperaktif.

Masa remaja seringkali disebut masa transisi yaitu masa peralihan dari masa kanak-kanak ke masa dewasa. Perkembangan selama masa remaja mencakup kematangan mental, emosional, sosial dan fisik. Syamsu Yusuf mengungkapkan.

Terkait dengan keberfungsian keluarga, seiring perkembangannya ada keluarga yang semakin kokoh dan keluarga yang mengalami keretakan atau ketidakharmonisan (disfungsional). Salah satu ciri disfungsi tersebut adalah perceraian orang tua, perceraian akan berdampak kurang baik terhadap kepribadian anak. Hal ini terungkap dalam hasil penelitian beberapa ahli, seperti: Mc Dermoot, Moorison, Offord, dkk., dalam Syamsu Yusuf bahwa remaja yang orang tuanya bercerai cenderung menunjukkan ciri-ciri: 1) berperilaku nakal, 2) mengalami depresi, 3) melakukan hubungan seksual secara aktif, 4) kecenderungan terhadap obat terlarang. Keadaan keluarga yang tidak harmonis, berantakan (broken home) merupakan faktor penentu bagi berkembangnya kepribadian anak yang tidak sehat. (2014:44)

Dapat disimpulkan bahwa remaja broken home cenderung mengalami banyak masalah emosional, moral, medis dan sosial. Kondisi keluarga akan menentukan bentuk penyesuaian diri pada remaja. Remaja adalah individu yang tidak lepas dari perkembangan dan pertumbuhan, tetapi bila tugas-tugas perkembangan ada yang 
terganggu, maka remaja tidak akan mampu mengembangkan kemampuannya secara optimal seperti yang diharapkan. Namun, kenyataannya sekarang kondisi yang dialami remaja ialah kondisi keluarga yang berantakan atau dikenal dengan broken home. Hurlock menyatakan bahwa,

Perkembangan yang dialami remaja di antaranya perkembangan sosial. Tugas perkembangan masa remaja yang sulit adalah berhubungan dengan penyesuaian sosial. Remaja harus menyesuaikan diri dengan teman sebaya khususnya lawan jenis, orang dewasa di luar keluarga dan sekolah. Salah satu ciri-ciri dari masa remaja adalah masa remaja sebagai usia bermasalah. $(2003: 208)$

Hal ini berarti pada usia remaja permasalahan semakin kompleks dan mereka memerlukan bantuan untuk mengatasi permasalahan mereka tersebut. Usia remaja adalah di mana mereka berada di bangku Sekolah Menengah Atas (SMA). Permasalahan-permasalahan yang dialami remaja tersebut memiliki latar belakang yang berbeda-beda, seperti: fisik, psikis, kematangan intelektual, sosial, moral dan emosional, lingkungan dan penentuan kultural. Salah satunya permasalahan keluarga (broken home) dan lingkungan sosial.

Masa remaja merupakan masa di mana seseorang sedang mengalami saat kritis sebab ia akan menginjak ke masa dewasa. Pada saat itulah remaja mengalami kelabilan dalam emosi, sikap dan perilakunya dalam proses pencarian identitas diri. Di masa transisi inilah remaja membutuhkan perhatian dan bantuan dari orang yang dicintai dan dekat dengannya terutama orang tua atau keluarganya. Seperti yang telah diketahui bahwa fungsi keluarga adalah memberi pengayoman sehingga menjamin rasa aman, maka dalam masa kritisnya remaja sungguh-sungguh membutuhkan realisasi fungsi tersebut. Keluarga dan sekolah memiliki pengaruh yang sangat penting untuk membantu perkembangan siswi dan membantu mengatasi permasalahan-permasalahan dalam hidupnya. Apalagi, dewasa ini permasalahan-permasalahan yang dihadapi oleh para remaja semakin kompleks. Sementara Willis (2009:66) mengatakan:

Keluarga pecah (broken home) dapat dilihat dari dua aspek yaitu (1) keluarga itu terpecah karena strukturnya tidak utuh sebab salah satu dari kepala keluarga itu meninggal dunia atau telah bercerai, (2) orang tua tidak bercerai akan tetapi struktur keluarga itu tidak utuh lagi karena ayah atau ibu sering tidak di rumah, atau tidak memperlihatkan kasih sayang lagi. 
Misalnya orang tua sering bertengkar sehingga keluarga itu tidak sehat secara psikologis.

Dari pengertian broken home di atas dan dengan keadaan keluarga masih tinggal serumah ataupun yang sudah bercerai tetap saja memberikan dampak yang buruk pada anak, di mana sebetulnya anak masih memerlukan bimbingan orang tua sampai anak lepas masa lajang. Akibat kondisi orang tua yang mengalami broken home, maka lebih banyak anak belajar beragam hal dari lingkungan, teman sebaya, dan bukan dari kedua orang tuanya. Lebih lanjut dikemukakan oleh Willis (2009:66) bahwa,

Keluarga dan sekolah merupakan dua sistem yang amat penting dalam kehidupan anak dan remaja. Keluarga berperan utama dalam mempengaruhi anak-anak dalam proses perkembangan dan sosialisasinya. Anak-anak belajar pola-pola awal perilaku, berkomunikasi, menyatakan perasaan, belajar nilainilai dan sikap dari keluarga inti dan keluarga besar. Hal ini dibuktikan oleh hasil penelitian Sunaryo Kartadinata yang menemukan, Korelasi sederhana antara iklim kehidupan keluarga dengan adekuasi penyesuaian diri sebesar $r$ $=0,393$ dan signifikan pada tingkat kepercayaan 0,01. Berarti sumbangan iklim keluarga terhadap penyesuaian diri adalah lebih kurang $16 \%$. Mungkin terhadap perilaku lainnya seperti perilaku emosional, keadaan angka itu akan bertambah besar.

Banyak pula dari permasalahan-permasalahan yang dialami para remaja tersebut berasal dari keluarga, permasalahan yang dilatarbelakangi oleh permasalahan keluarga, seperti broken home bisa menimbulkan berbagai perilaku negatif, baik dalam segi kepribadian maupun sosio-emosionalnya. Keluarga merupakan lingkungan utama yang memberikan pengaruh terhadap berbagai aspek perkembangan anak/remaja. Kondisi keluarga yang harmonis akan menghasilkan penyesuaian diri yang positif, sebaliknya broken home menghasilkan penyesuaian diri yang negatif berupa konflik, frustasi dan kebingungan. Sangatlah penting untuk memahami berbagai faktor yang mempengaruhi proses penyesuaian diri remaja. Hal itu dapat dimaksudkan untuk mengantisipasi berbagai masalah yang akan muncul dalam proses penyesuaian diri remaja baik di lingkungan keluarga, sekolah maupun masyarakat dan mencegah berbagai pengaruh negatif yang menjadi kendala bagi perkembangan diri remaja.

Dari semua fenomena di atas, broken home akan berdampak pada perkembangan psikologis anak dalam keluarga itu. Remajalah yang dalam hal ini 
sangat rentan. Pengaruh faktor broken home menjadi faktor negatif dalam penemuan identitas yang sehat/penyesuaian diri, sehingga remaja cenderung mengalami fase kebingungan identitas. Perkembangan afeksi juga bisa mengalami hambatan. Hal ini dikarenakan adanya pengabaian oleh orang tuanya.

Salah satu tugas perkembangan remaja ialah penyesuaian diri. Penyesuaian diri pada remaja sangatlah penting, di mana penyesuaian diri pada masa ini dapat menentukan sikap dan psikologi remaja pada masa yang akan datang. Jika remaja sulit atau tidak bisa menyesuaikan diri pada lingkungan di mana dia berada akan berdampak buruk pada perkembangan diri anak itu sendiri, baik pada masa penyesuaian ataupun pada masa yang akan datang. Enung Fatimah (2006:194) mengemukakan, "penyesuaian diri merupakan suatu proses alamiah dan dinamis yang bertujuan mengubah perilaku individu agar terjadi hubungan yang lebih sesuai dengan kondisi lingkungan". Dan "penyesuaian diri yang positif dan penyesuaian diri yang salah".

Berdasarkan pendapat di atas dapat diambil kesimpulan bahwa penyesuaian diri terbagi dua, yaitu penyesuaian diri positif yang membuat individu diterima dengan baik oleh lingkungan, sementara penyesuaian diri yang negatif akan membuat individu ditolak oleh lingkungannya. Untuk itu, agar terhindar dari penyesuaian diri yang negatif maka perlu ditanamkan dalam diri remaja sejak dini bahwa setiap permasalahan yang dialami, dari yang ringan sampai yang kompleks harus dipikirkan secara realistik. Penyesuaian diri yang salah pada diri remaja akan melahirkan tingkah laku yang menyimpang. Remaja yang penyesuaian dirinya salah akan melakukan tindakan yang salah pula. Salah satunya karena lingkungan keluarga yang tidak berfungsi seperti, "broken home”. Remaja yang penyesuaian dirinya negatif, akan memunculkan tingkah laku dan sikap yang ditolak oleh lingkungan, sehingga kesulitan dalam melakukan hubungan sosial dengan orang lain. Hal ini dikarenakan dasar penting terbentuknya suatu pola penyesuaian diri adalah kepribadian. Setidaknya ada tiga faktor yang dapat mempengaruhi proses penyesuaian diri remaja, salah satu di antaranya kondisi lingkungan, khususnya keluarga dan sekolah" (Ghufron \& Rini, 2011:55). 
Fenomena di lapangan saat ini semakin maraknya kasus broken home yang sangat berdampak khususnya dalam penyesuaian diri remaja. Remaja yang dikenal sebagai usia bermasalah membutuhkan bimbingan khususnya dari orang tua/keluarga. Jadi, salah satu penyebab penyesuaian diri menjadi positif dan negatif dipengaruhi oleh faktor lingkungan yaitu keluarga dan sekolah. Keluarga menjadi penentu kesuksesan penyesuaian diri remaja, seperti: keluarga berantakan cenderung memunculkan penyesuaian diri negatif pada remaja, sedangkan kondisi keluarga harmonis akan lebih memantapkan remaja dalam menyesuaikan diri secara positif. Remaja yang berasal dari keluarga yang berantakan akan berpengaruh terhadap penyesuaian dirinya.

Berdasarkan hasil observasi ditemukan bahwa siswi yang orang tuanya bercerai lebih cenderung menyendiri selain itu siswi juga sulit menerima kritikan dari orang lain dan juga berpengaruh terhadap hasil belajarnya. Sementara menurut pengakuan dari salah satu siswi yang orang tuanya bercerai bahwa ia merasa malu dan juga sedih sama teman-teman yang lainnya apabila mereka membicarakan tentang orang tua mereka dan menyinggung masalah perceraian orang tuanya, jadi ia lebih memilih untuk menyendiri dari pada berkumpul dengan teman-temannya yang lain. Siswi mengakui mengalami kesulitan dalam berbicara dengan orang lain. Selain itu Siswi juga lebih memilih diam dari pada melakukan sesuatu.

Peneliti berpendapat bahwa anak dalam keluarga broken home cenderung mempunyai penilaian yang negatif terhadap orangtua yang dianggapnya menjadi penyebab keretakan dalam keluarga. Di samping itu, kondisi keluarga yang tidak harmonis seperti pertengkaran dalam rumah tangga dan terjadinya perceraian akan menyebabkan konflik, kebingungan yang menyebabkan ia tidak mampu melakukan penyesuaian diri terhadap lingkungannya dan frustasi. Akhirnya muncullah gejalagejala kenakalan atau perilaku menyimpang seperti menantang atau bermusuhan dengan lingkungan, mengganggu ketertiban umum, melanggar norma agama, norma masyarakat dan sebagainya. Menurut Andriana dalam Annisa (2008:8)

Broken home sangat berpengaruh besar pada penyesuaian diri seorang remaja. Hal inilah yang mengakibatkan seorang remaja berperilaku menyimpang. Broken home juga bisa merusak jiwa remaja sehingga dalam sekolah mereka bersikap seenaknya saja, tidak disiplin di dalam kelas, mereka 
selalu berbuat keonaran dan kerusuhan. Hal ini dilakukan karena mereka cuma ingin mencari simpati dari teman-teman mereka bahkan dari guru-guru mereka.

Pada umumnya penyebab utama broken home ini adalah kesibukan kedua orang tua dalam mencari nafkah keluarga, seperti halnya seorang ayah bekerja dan ibu menjadi wanita karir. Perubahan struktur keluarga inilah yang memicu remaja berperilaku menyimpang dan mengalami penyesuaian diri yang negatif. Ahli perkembangan Catherine Cooper dan kawan-kawannya dalam Santrock telah memperlihatkan bahwa, "Kehadiran suasana kekeluargaan yang mendukung, baik individualitas dan keterkaitan, perannya penting dalam perkembangan identitas remaja" (2002:59). Dikemukakan bahwa anak/remaja yang dibesarkan dalam lingkungan sosial keluarga yang tidak baik/disharmoni keluarga, maka resiko anak untuk mengalami gangguan kepribadian menjadi berkepribadian antisosial dan berperilaku menyimpang lebih besar dibandingkan dengan anak/remaja yang dibesarkan dalam keluarga sehat/harmonis (sakinah).

Fenomena di MAN 2 Tanah Datar menunjukkan bahwa beberapa siswi broken home ada yang memiliki bentuk penyesuaian diri yang tidak sesuai. Namun, uniknya disini juga ditemukan Siswi broken home yang mampu beradaptasi dan menyesuaikan diri dengan lingkungannya. Bagi Siswi tersebut broken home bukanlah alasan yang menyebabkan dia berperilaku negative, seperti ditemukan siswi broken home yang aktif berorganisasi, memiliki banyak teman (hubungan sosial) yang baik dan berprestasi baik akademik maupun non akademik. Hasil observasi peneliti di MAN 2 Tanah Datar ditemukan 3 orang siswi broken home yang berprestasi. Bagi mereka, prestasi dan penerimaan lingkungan sangat berarti bagi mereka. Jika mereka berprestasi dan diterima oleh lingkungan, berarti mereka dapat menjalin hubungan sosial yang baik. Namun, lingkungan yang tidak menerima perbedaan mereka akan menyulitkan mereka terutama dalam penyesuaian diri dengan lingkungannya.

\section{METODE PENELITIAN}

Penelitian ini menggunakan pendekatan kualitatif dengan tujuan untuk menggambarkan tentang bentuk penyesuaian diri siswi yang berasal dari keluarga 
broken home di MAN 2 Tanah Datar. Informan ditentukan dengan teknik purpossive sampling. Dalam penelitian ini yang menjadi pertimbangan peneliti adalah bahwa Siswi berasal dari keluarga bermasalah/broken home yang memiliki prestasi akademik dan non akademik. Penelitian dilakukan pada 26 April 2017 sampai 26 Juni 2017. Data diperoleh dengan melakukan observasi langsung (participant observation) dan wawancara mendalam (depth interview).

Untuk menjamin kualitas keabsahan data peneliti melakukan wawancara secara langsung kepada sumber data, tidak ada wawancara yang diwakilkan kepada orang lain. Peneliti juga melakukan verifikasi data jika terdapat data yang kurang jelas. Pembacaan teori juga peneliti lakukan selama proses penelitian berlangsung untuk menjaga keabsahan data. Teknis analisis data dilakukan dengan analisis model Mailis Huberman. Abdul Halim Hanafi (2015) menjelaskan bahwa analisis model Mailis Huberman digunakan untuk mendapatkan data yang valid dan jenuh. Dengan langkah mereduksi data, mendisplay data, memverifikasi data dan menyimpulkan data.

\section{PAPARAN HASIL PENELITIAN}

Berdasarkan hasil observasi yang peneliti lakukan di MAN 2 Tanah Datar pada 02-05 Februari 2016, ditemukan dari 20 orang siswa broken home, 3 orang di antaranya perempuan yang memiliki prestasi. Dari hasil observasi diperoleh data bahwa Siswi broken home dengan penyesuaian diri yang positif menunjukkan perilaku positif seperti: serius dan sungguh-sungguh dalam belajar, berkomunikasi baik dengan guru dan teman, tidak melanggar tata tertib sekolah serta aktif baik di kelas maupun dalam kegiatan ekstrakurikuler. Namun, ditemukan perbedaan antara penyesuaian diri di rumah dan di sekolah. Siswi broken home memiliki penyesuaian diri yang positif di sekolah, sedangkan di rumah seringkali terkendala untuk menjalin hubungan sosial yang baik dengan anggota keluarga, karena perubahan struktur dan suasana keluarga. Siswi broken home dengan penyesuaian diri yang positif di sekolah, agar mereka dapat diterima oleh lingkungan dengan perbedaan yang mereka miliki sehingga mereka memperlihatkan gambaran diri yang positif untuk dapat bergaul dan menjalin hubungan sosial yang baik dengan lingkungan. Dari 3 orang siswi broken home di MAN 2 Tanah Datar memiliki prestasi akademik 
dan non-akademik, seperti: juara kelas, aktif organisasi, mampu mengoptimalkan potensi yang dimilikinya. Jadi, kondisi mereka bukan penghalang untuk berprestasi baik akademik maupun non-akademik.

Penyesuaian diri Siswi broken home di MAN 2 Tanah Datar, ada penyesuaian diri positif dan penyesuaian diri yang salah. Hal menarik di sini ada 3 siswi broken home yang berprestasi, di mana siswi tersebut mampu beradaptasi dan menyesuaikan diri dengan lingkungan yang ada meskipun kondisinya berbeda dengan kebanyakan siswi lainnya. Bagi siswi tersebut kondisi broken home bukan penghalang baginya untuk bersosialisasi, berprestasi dan mengembangkan potensi yang dimilikinya. Meskipun ada siswi broken home yang mengalami kesulitan dalam menjalin hubungan di rumah karena perubahan struktur dan kondisi keluarga yang berbeda dari sebelumnya, namun mereka di sekolah mampu bersosialisasi dengan baik. Penyesuaian diri positif yang berhasil dimunculkan siswi broken home seperti: aktif organisasi, berprestasi akademik dan non akademik, hubungan sosial yang baik dengan guru, teman dan personil sekolah lainnya. Mengenai prestasi belajar maka terungkap bahwa broken home bisa mempengaruhi prestasi belajar Siswi apabila Siswi memiliki penyesuaian diri yang salah dan broken home bisa tidak mempengaruhi prestasi belajar siswi apabila siswi tersebut memiliki penyesuaian diri positif. (Hasil wawancara dengan Guru BK MAN 2 Tanah Datar pada 26-28 April 2017)

Peneliti melakukan wawancara mendalam dengan 3 orang siswi broken home yang memiliki penyesuaian diri positif dan berprestasi di MAN 2 Tanah Datar. Kondisi broken home dapat dipengaruhi oleh berbagai faktor termasuk salah satunya keluarga. Broken home yang dialami siswi beraneka ragam diantaranya: Ibu meninggal Ayah bersikap cuek, Orang Tua bercerai tinggal bersama Ibu, Orang Tua bercerai tinggal bersama saudara Ibu. Suasana dan struktur keluarga yang berubah akan berpengaruh terhadap penyesuaian diri siswi di lingkungan. Berdasarkan hasil wawancara dengan ketiga siswi broken home di MAN 2 Tanah Datar, dapat dipahami bahwa penyesuaian diri bagi mereka merupakan suatu hal yang penting. Karena, menurut mereka jika tidak ada penyesuaian diri yang baik, 
berarti mereka tidak diterima oleh lingkungannya. Penyesuaian diri menjadi penentu posisi dan kedudukan mereka di suatu lingkungan. Mereka menganggap jika penyesuaian diri baik maka mereka mampu menjalin hubungan sosial yang baik dengan lingkungan dan adanya perasaan dihargai oleh lingkungan di mana mereka berada. Mereka merasa tidak berarti ketika lingkungan bersikap cuek dan mengabaikan keberadaan mereka. Namun, lingkungan yang peduli dan menaruh perhatian serta simpati sangat mendorong mereka untuk berprestasi dan mengembangkan potensi yang dimilikinya.

Sikap yang dimunculkan siswi broken home ketika ada masalah di sekolah yaitu: mampu mengontrol emosi, introspeksi diri, memiliki pertimbangan dalam mengambil tindakan, mampu mengambil hikmah suatu kejadian, bersikap realistis dan objektif. Berdasarkan pendapat di atas dapat disimpulkan bahwa dari tiga Siswi broken home yang diwawancarai semuanya memiliki usaha yang berbeda-beda untuk mengembangkan potensi yang dimilikinya, diantaranya: mengikuti kegiatan ekstrakurikuler, mempertahankan prestasi akademik dan non akademik, kegiatan keagamaan, liqo', Rohis, menjadi perangkat lokal dan aktif dalam kegiatan fornis. Untuk peran di lingkungan sosial mereka mewujudkan gambaran diri positif, karena mereka ingin membuktikan broken home bukan penghalang bagi mereka untuk bersosialisasi dengan lingkungan. Kondisi mereka bukan sesuatu yang memalukan, sehingga mereka ingin mewujudkan potensi diri yang dapat merubah gambaran diri mereka di masyarakat. Mereka mampu menjalin hubungan sosial yang baik di masyarakat dengan cara tidak melakukan aktifitas yang melanggar norma dan tata aturan nilai yang berlaku.

Berdasarkan pendapat di atas dapat disimpulkan bahwa dari tiga orang siswi broken home yang menjadi subjek penelitian, semuanya mengungkapkan bahwa dalam menjalin hubungan sosial di rumah lebih banyak yang mengalami hambatan dibanding dalam menjalin hubungan sosial di sekolah. Hambatan yang dialami dalam menjalin hubungan sosial di rumah, yaitu: sikap orang tua yang terkesan cuek dalam menjalin komunikasi dengan anak, tingginya ego untuk dihargai dan selalu didengarkan dalam keluarga dan perasaan sendiri dan merasa kesepian karena tidak memiliki tempat berbagi. Namun, karena adanya motivasi dari dalam diri dan 
lingkungan lainnya sehingga tiga orang siswi broken home yang menjadi subjek penelitian mampu berprestasi akademik dan non akademik.

Namun, siswi broken home mampu memiliki penyesuaian diri positif karena banyak faktor yang mempengaruhinya, seperti: memiliki pertimbangan yang rasional dalam pengarahan diri, ingin merubah nasib, ingin membanggakan keluarga, motivasi dari guru ngaji, mampu belajar dari pengalaman, bersikap realistik dan objektif, motivasi keluarga, tidak ingin kejadian yang sama terulang kembali, ingin sukses dengan usaha sendiri dan belajar dari pengalaman. Jadi, broken home dapat tidak berpengaruh terhadap prestasi apabila individu tersebut memiliki kematangan sosial dan emosional yang baik. Individu yang tidak memiliki ketegangan emosi, tidak mengalami frustasi, memiliki pertimbangan dalam mengambil suatu keputusan/tindakan akan mampu belajar dan berpikir realistis serta objektif.

Berdasarkan observasi, dokumentasi dan wawancara yang peneliti lakukan, penyesuaian diri yang berbeda-beda pada siswi broken home di MAN 2 Tanah Datar dipengaruhi oleh faktor-faktor berikut: kondisi fisik, perkembangan dan kematangan, penentuan psikologis, kondisi lingkungan dan penentuan kultural termasuk agama. Faktor yang mempengaruhi penyesuaian diri Siswi berkaitan erat dengan faktor yang mengatur perkembangan dan terbentuknya pribadi individu secara bertahap. Enung Fatimah juga mengemukakan penyesuaian diri dipengaruhi oleh faktor-faktor yang menentukan kepribadian itu sendiri, baik internal maupun eksternal. Faktor tersebut adalah: "1) faktor fisiologis, 2) faktor psikologis, 3) faktor perkembangan dan kematangan, 4) faktor lingkungan, 5) faktor budaya dan agama" (2006:199). Berdasarkan pendapat ahli di atas dapat dipahami bahwa secara umum, faktor yang mempengaruhi penyesuaian diri siswi terbagi dua, yaitu faktor internal dan faktor eksternal. Faktor internal merupakan faktor meliputi kondisi jasmani, psikologis, kebutuhan, kematangan intelektual, emosional, mental dan motivasi. Faktor eksternal merupakan faktor yang berasal dari luar diri individu seperti kondisi lingkungan yang meliputi lingkungan keluarga, sekolah, masyarakat dan lingkungan teman sebaya. 
Penyesuaian diri siswi broken home di rumah, seringkali memunculkan penyesuaian diri yang salah, sebagai bentuk pelampiasan kekesalannya. Hal itu disebabkan karena: perubahan suasana kekeluargaan dan perubahan status di keluarga. Reaksi yang banyak dimunculkan Siswi broken home dalam menghadapi permasalahan di rumah, yaitu: menentang, membangkang, mengintrospeksi diri, ikhlas atas nasibnya, bersikap keras pada lingkungan dan memendam permasalahan yang dialaminya. Namun, sikap positifnya yang bisa diambil yaitu: merutinkan shalat dan membaca Al-Qur'an, tidak berputus asa, menjalin hubungan silaturahmi dan komunikasi yang baik, sabar dan senantiasa mensyukuri keadaan yang ada. Cara mereka dalam menyikapi permasalahan yang ada, yaitu: lari dari masalah, menghindar, menutup diri, bersikap keras pada lingkungan dan memendam permasalahan yang dialaminya. Hal ini akan lebih baik, karena jika mereka terus bertahan di rumah dengan kondisi yang tidak nyaman tersebut akan berdampak yang jauh lebih buruk dari pada mereka meninggalkan rumah dengan mencari pelarian, asalkan pelarian yang mereka lakukan tidak melanggar norma dan etika yang ada. Karena dalam kondisi broken home suasana dan struktur keluaga yang berbeda dari keluarga normal lainnya, makna rumah akan sangat berbeda mereka definisikan. Bagi siswi broken home rumah bukanlah sebagai tempat berlindung dan istirahat yang nyaman, melainkan sebagai sumber masalah yang akan membuat lebih depresi dan akan mengganggu proses belajar yang mereka jalani. Jadi akan lebih baik jika mereka meninggalkan rumah untuk mengantisispasi hal buruk lainnya yang mungkin terjadi. Jadi, anak yang memperoleh contoh penyesuaian diri negatif di keluarga, namun bisa menyesuaikan diri secara positif di sekolah karena adanya faktor lingkungan di luar keluarga yang membantu anak dalam membentuk penyesuaian diri positif di lingkungannya, seperti: motivasi dari Guru BK, motivasi dari Guru ngaji terutama motivasi dari dalam diri anak itu sendiri.

Hambatan dalam menjalin hubungan sosial di rumah lebih banyak di banding dalam menjalin hubungan sosial di sekolah. Hambatan yang dialami dalam menjalin hubungan sosial di rumah, yaitu: sikap orang tua yang terkesan cuek dalam menjalin komunikasi dengan anak, tingginya ego untuk dihargai dan selalu didengarkan dalam keluarga serta perasaan sendiri dan merasa kesepian karena 
tidak memiliki tempat berbagi. Namun, penyesuaian diri positif yang berhasil dimunculkan siswi broken home di rumah karena adanya motivasi dari lingkungan. Jadi, penyesuaian diri terbagi dua, yaitu penyesuaian diri positif yang membuat individu diterima dengan baik oleh lingkungan, sementara penyesuaian diri yang negatif akan membuat individu ditolak oleh lingkungannya. Untuk itu, agar terhindar dari penyesuaian diri yang negatif maka perlu ditanamkan dalam diri remaja sejak dini bahwa setiap permasalahan yang dialami, dari yang ringan sampai yang kompleks harus dipikirkan secara realistik.

Bagi siswi broken home penyesuaian diri merupakan suatu hal yang penting. Karena, menurut mereka jika tidak ada penyesuaian diri yang baik, berarti mereka tidak diterima oleh lingkungan. Penyesuaian diri menjadi penentu posisi dan kedudukan mereka di suatu lingkungan. Mereka menganggap jika penyesuaian diri baik maka mereka mampu menjalin hubungan sosial yang baik dengan lingkungan dan adanya perasaan dihargai oleh lingkungan di mana mereka berada. Mereka merasa tidak berarti ketika lingkungan bersikap cuek dan mengabaikan keberadaan mereka. Namun, lingkungan yang peduli dan menaruh perhatian serta simpati sangat mendorong mereka untuk berprestasi dan mengembangkan potensi yang dimilikinya.

Jadi, dapat diartikan bahwa penyesuaian diri merupakan suatu usaha yang dilakukan oleh individu untuk menghadapi berbagai tuntutan, baik dari dalam diri maupun dari lingkungan individu tersebut, sehingga ia mendapatkan hubungan yang serasi dan harmonis dengan orang lain maupun lingkungannya. Setiap individu mempunyai kemampuan penyesuaian diri yang berbeda-beda. Hal ini dikarenakan perbedaan sudut pandang dan perbedaan karakter dari masing-masing individu tersebut. Keberhasilan seseorang dalam proses penyesuaian diri terletak pada kemampuan individu tersebut untuk saling menyesuaikan sudut pandang terhadap lingkungan. Perbedaan sudut pandang antara individu dengan lingkungan akan menimbulkan gangguan dalam penyesuaian diri. Untuk itu, agar tercapai penyesuaian diri yang baik maka individu harus mampu saling memberi dan menerima secara terbuka. 
Tiga siswi broken home yang diwawancarai semuanya sudah memiliki gambaran mengenai tujuan masa depan yang jelas. Tujuan masa depan yang diungkapkan seperti: ingin melanjutkan pendidikan, membanggakan keluarga, bentuk pembuktian bahwa siapapun dengan kondisi apapun bisa sukses dan meraih kesuksesan, berwirausaha dan menyatukan keluarga. Semuanya memiliki usaha yang berbeda-beda untuk mengembangkan potensi yang dimilikinya, diantaranya: mengikuti kegiatan ekstrakurikuler, mempertahankan prestasi akademik dan non akademik, kegiatan keagamaan, liqo', Rohis, menjadi perangkat lokal dan aktif dalam kegiatan fornis. Untuk peran di lingkungan sosial mereka mewujudkan gambaran diri positif, karena mereka ingin membuktikan broken home bukan penghalang bagi mereka untuk bersosialisasi dengan lingkungan. Kondisi mereka bukan sesuatu yang memalukan, sehingga mereka ingin mewujudkan potensi diri yang dapat merubah gambaran diri mereka di masyarakat. Mereka mampu menjalin hubungan sosial yang baik di masyarakat dengan cara tidak melakukan aktifitas yang melanggar norma dan tata aturan nilai yang berlaku.

Broken home bisa mempengaruhi prestasi belajar siswi apabila siswi memiliki penyesuaian diri yang salah dan broken home bisa tidak mempengaruhi prestasi belajar siswi apabila siswi tersebut memiliki penyesuaian diri positif. Semuanya memiliki motivasi yang berbeda-beda untuk mengembangkan potensi yang dimilikinya, diantaranya: motivasi dari guru BK, motivasi dari guru ngaji, keluarga, pembuktian diri dan keyakinan serta kesungguhan diri.

Broken home merupakan suatu hal yang subjektif bagi setiap individu, karena setiap individu memiliki persepsi dan pandangan yang berbeda mengenai broken home. Dari tiga orang siswi broken home yang memiliki penyesuaian diri positif di MAN 2 Tanah Datar, yang menjadi subjek penelitian ini memiliki latar belakang yang berbeda-beda, diantaranya: salah satu orang tua (Ibu) meninggal dan orang tua bercerai. Jadi, dari ketiga siswi broken home yang menjadi subjek penelitian memiliki latar belakang yang berbeda-beda. Sikap dan reaksi yang mereka munculkan dalam menyikapi kondisinya juga berbeda-beda. Hal itulah yang menimbulkan dampak yang berbeda juga terhadap perkembangan psikologis mereka ke depannya. 
Dampak psikologis yang dialami siswi broken home di atas diantaranya: kasus RKM anak piatu. RKM hanya punya Ayah sebagai orang tua satu-satunya yang diharapkan dapat memberikan perhatian dan kasih sayang yang didambakannya. Orang tua seharusnya menjadi teladan dan panutan bagi anak untuk bersikap dan bertingkah laku. Sikap orang tua seharusnya melindungi dan membuat anak merasa aman dan nyaman berada di lingkungan keluarganya. Namun, sikap orang tua yang cuek membuat anak menjadi serba salah dalam bersikap. Bagi SF dan ZF dengan kasus orang tua bercerai mengalami dampak psikologis sebagai berikut: pola pikir SF menjadi salah, sehingga menimbulkan tingkah laku yang salah suai di mana SF menjadi membenci lawan jenis, karena takut dan cemas akibat pengalaman masa lalunya. ZF mengalami tekanan tidak hanya dengan kondisi Ayah dan Ibunya yang bercerai, namun dari sikap, perbuatan dan kata-kata yang dilontarkan Bundanya membuat ZF terpaksa harus memendam sendiri kesedihan yang dialaminya.

\section{PENUTUP}

Dari hasil penelitian dan pembahasan yang telah diuraikan sebelumnya, maka dapat disimpulkan bahwa bentuk enyesuaian diri yang ditunjukkan siswi berebda ketika di rumah dan di sekolah. Di rumah mereka cenderung menunjukkan penyesuaian diri negatif. Namun, ketika di sekolah mereka mampu menyesuaikan diri dan memiliki prestasi. Penyesuaian diri siswi broken home di MAN 2 Tanah Datar dipengaruhi oleh faktor-faktor berikut: kematangan emosional, kondisi lingkungan keluarga dan sekolah. 


\section{DAFTAR PUSTAKA}

Al-Mighwar. M. 2006. Psikologi Remaja, Bandung: Pustaka Setia

Annisa, R. 2008. “Dampak Broken Home terhadap Minat Belajar”, Skripsi Sarjana, Fakultas Ilmu Sosial dan Ilmu Politik, UNILA, Lampung

Arikunto, S. (Eds). 2010. Prosedur Penelitian Suatu Pendekatan Praktek, Jakarta: Rineka Cipta

Dagun. (Eds). 2002. Psikologi Keluarga, Jakarta: Rineka Cipta

Desmita. 2009. Psikologi Perkembangan Peserta Didik, Bandung: Rosdakarya

Fatimah. E. 2006. Psikologi Perkembangan (Perkembangan Peserta Didik), Bandung: CV Pustaka Setia

Fauziah. M. 2013. “Konsep Diri Remaja yang Berasal dari Keluarga Broken Home Studi Deskriptif di SMP Negeri 1 Pantai Cermin Kabupaten Solok," Skripsi Sarjana, STKIP PGRI Sumatera Barat, Padang

Gerungan. 2004. Psikologi Sosial, Bandung: Refika Aditama

Ghufron, M.N \& Risnawita. S. 2011. Teori-Teori Psikologi, Yogjakarta: Ar-Ruzz Media

Hanafi, A. H. 2015. Metodologi Penelitian Kependidikan, Jakarta: Diadit Media

Hurlock. (Eds). 2003. Psikologi Perkembangan Suatu Pendekatan Sepanjang Rentang Kehidupan, Jakarta: Erlangga

Imam Gunawan. 10 April 2010. Konsep Penyesuaian Diri, Tersedia: http://masimamgun.blogspot.com/2010/04/konsep-penyesuaian diri.html,

Jahja, Y. 2011. Psikologi Perkembangan, Jakarta: Kencana

Putri, R. N. 2013. "Perceraian Orang Tua dan Penyesuaian Diri Remaja Studi Pada Siswi SMA/SMKN di Kota Samarinda," Skripsi Sarjana Samarinda Putri, W. 2013. “Korelasi antara Interaksi Teman Sebaya dengan Penyesuaian Diri Siswi di SMPN 1 Padang Ganting," Skripsi Sarjana, Fakultas Tarbiyah IAIN Batusangkar, Batusangkar

Rahmi. M. 2013. "Kontrol Diri Siswi Broken Home Kelas XI di SMK Cendana Padang Panjang," Skripsi Sarjana, Fakultas Tarbiyah IAIN Batusangkar, Batusangkar 
Rumini, S \& Sundari, S. 2004. Perkembangan Anak dan Remaja, Jakarta: Rineka Cipta

Santrock, J.W. 2002. Perkembangan Masa Hidup, Jilid II, Jakarta: Erlangga

Sudarsono. 2008. Kenakalan Remaja, Jakarta: Rineka Cipta

Sugiyono. 2013. Metode Penelitian Kuantitatif, Kualitatif dan R\&D, Bandung: Alfabeta

Sujoko. 2011. "Hubungan antara Keluarga Broken Home, Pola Asuh Orang Tua dan Interaksi Teman Sebaya dengan Kenakalan Remaja,", Tesis, Fakultas Psikologi Universitas Setia Budi, Surakarta

Thayib. 1992. Struktur Rumah Tangga Muslim, Surabaya: Risalah Gusti

Willis, S.S. 2009. Konseling Keluarga (Family Counseling), Bandung: Alfabeta

Yusuf, S. (Eds). 2014. Psikologi Perkembangan Anak dan Remaja, Bandung: Rosdakarya 